\title{
BUCKOVÁ, Martina a kol.: Reflexia mytologických motívov v duchov- nej a materiálnej kultúre národov Ázie, Afriky a Oceánie. Bratislava : Ústav orientalistiky SAV, 2019. 272 s. ISBN 978-80-89867-04-2
}

\author{
DOI: https://doi.org/10.24040/ahn.2020.23.02.265-270
}

V domácom prostredí vychádza pomerne málo literatúry venovanej duchovnej kultúre Ázie, Afriky či Oceánie, preto akákol'vek lastovička $\mathrm{v}$ tomto odbore robí radost' záujemcom z odborných radov i laickej verejnosti. Ústav orientalistiky SAV minulý rok vydal zborník s názvom Reflexia mytologických motívov v duchovnej a materiálnej kultúre národov Ázie, Afriky a Oceánie. V rozsahu 272 strán dostalo priestor celkom jedenást' štúdií z rôznych kútov Blízkeho a Ďalekého východu. Každá štúdia sa venuje inej geografickej oblasti s výnimkou Číny a Japonska, ku ktorým sa viažu dva príspevky od dvoch rôznych autorov.

Široký geografický rámec, ktorý otvára táto publikácia predstavuje nekonečné množstvo materiálu, ktorý môže u čitatel'a vzbudzovat' dojem nesúrodosti. Zborník nemá historické či chronologické vymedzenie a v danom geografickom priestore nachádzame vel'mi širokú škálu náboženstiev. Môžeme teda premýšl'at' nad odrazom predkrest'anských reliktov u Koptov, v budhistických sektách či o mytologickom koncepte sveta vybraného kmeňa Oceánie. Publikácia vznikla s podporou grantu VEGA 2/0102/16 Reflexia kozmologických predstáv $v$ duchovnej a materiálnej kultúre Ďalekého Východu, južnej Ázie a Oceánie. Pôvodný názov grantu teda o niečo menej zužuje priestor, v ktorom sa mohli príspevky pohybovat'. Predsa len „reflexia mytologických motívov v duchovnej a materiálnej kultúre" je abstraktnejšou a širšou témou ako vymedzenie kozmologických predstáv. ${ }^{1}$

Úvod zborníka má jednu nezrovnalost', ktorá prešla aj cez poslednú redakciu textu. Štúdia, ktorá sa zaoberá hinduistickými samskárami je v úvode predstavená pojmom samsáry, pričom ide o dva odlišné termíny. Odobratím písmena „k“ vznikol preklep, ktorý mohol byt’ spôsobený bud' nepozornost'ou, alebo faktom, že pojem samsára je známejší a jedna z autoriek úvodu si ho pomýlila. Prejdime však v krátkosti k samotným príspevkom.

Prvá štúdia v zborníku pod názvom Političtí bohové a božští politici. Náboženství a politika ve starověké Mezopotamii je zároveň jediným príspevkom českého orientalistu Lukáša Pechu. Vo svojom príspevku Pecha

\footnotetext{
${ }^{1}$ Kozmológiu chápeme ako predstavy o usporiadaní sveta, okruh mýtov, ktorý sa zaoberá štruktúrou a usporiadaním vesmíru. KOVÁČ, Milan: Teória mýtu. Religionistické študijné texty. zv. 1. Bratislava : Univerzita Komenského v Bratislave, Filozofická fakulta, 2010, s. 5.
} 
oboznamuje čitatel'a s prameňom Sumerský zoznam král'ov, ktorý vymenúva jednotlivých panovníkov a vládnuce dynastie. Na základe legiend popisujúcich zasadnutie panovníka na trón, dostávame obraz o pôvode legitimity král'ovskej moci, ktorá bola vykonávaná výhradne s božským potvrdením. Zneuctenie božstva mohlo viest' k zosadeniu vládcu samotným božstvom, ako to bolo v prípade babylonského Nabonida, ktorý po svojich skutkoch už nebol v priazni boha Marduka. Božský pôvod král'ovskej moci je evidentným znakom náboženského fungovania človeka v staroveku, a to nielen v Mezopotámii, ale aj v iných kútoch sveta. Myslenie archaického človeka a jeho náboženský svet boli úzko späté s každodenným životom i s politickými záležitost’ami. Z tohto pohl'adu je takmer nemyslitel'né, aby sa sakrálny a profánny rozmer života oddel'oval, a to aj vrátane politiky. Fenomén človeka náboženského (Eliadeho kategória homo religiosus) sa vytrácal až s príchodom sekularizácie štátu, ktorá sa objavuje v dejinách pomerne neskoro.

Autorka D. Zhang Cziráková popisuje v štúdii Drak ako symbol čínskej národnej identity, jeho symbolika a zobrazovanie v čínskom umení úvod do danej problematiky. Text sprevádzajú fotografie vyobrazení draka, ktoré sú dielom autorky. Považujem ich za pozitívnu prílohu, ktorá dotvára celkový obraz popisovanej témy. V časti Odlišnosti vo vnímaní draka v čínskej kultúre v porovnaní so Západom Zhang Cziráková poukazuje na negatívne vykreslenie draka v európskej kultúre v súvislosti s krest'anstvom. Treba však dodat', že neskorší krest'anský súboj sv. Juraja drakobijcu je pozostatkom mytologickej látky indoeurópskych spoločností. Súboj hromovládcu s hadom (drakom) je prítomný v mnohých indoeurópskych mýtoch a pozostatky o ňom nachádzame aj vo folklóre. ${ }^{2}$ Tento prvok štúdia nespomína a považujem ho za vhodné doplnenie témy. Rovnako si nie som istý jednoznačnost'ou tvrdení o rozdielnosti pohl'adu na svet medzi Západom a Čínou: „Kým na Západe prevažuje antropocentrický pohl'ad na svet, kde je človek $v$ stredobode pozornosti a príroda je chápaná ako niečo, čo je tu kvôli nám a pre nás, ako niečo, čo treba skrotit', podrobit' si, zmenit' na obraz človeka a pretvorit' ju tak, aby bola akosi viac domestifikovaná" (s. 31 - 32). Zdôrazňuje sa, že v čínskom myslení a filozofii „človek nevstupuje s prírodou do konfliktu, nesnaží sa ju ovládnut', či podmanit' si ju silou, nebojuje s ňou, ale snaží sa nažívat' $s$ ňou v harmónii." (s. 33). V tomto prípade autorka neuvádza, či ide o nejakú historickú epochu západného sveta (na mysli má pravdepodobne západnú a strednú Európu), alebo súčasný západný svet, nakol'ko pojem antropocentrizmu je skôr moderný. Druhý citát považujem

\footnotetext{
2 K mytologickému súboju draka a hromovládcu odporúčam publikáciu: PUHVEL, Jaan: Srovnávací mythologie. Praha : Nakladatelství Lidové noviny, 1997. 395 s.
} 
za zjednodušenie. Polemizovat' by sa isto dalo aj s výrokmi o traumatickom zobrazení draka v európskej kultúre. Ďalšie časti tejto štúdie už neprinášajú rozpory a zobrazovanie drakov v materiálnej kultúre so sprievodnými príkladmi fotografií považujem za najhodnotnejšiu čast'.

V d’alšej štúdii Revenant Bórei a jeho vítanie ako návštevníka Marebito v ranom Kabuki manuskriptov Okuni Sóši sa presúvame do Japonska. Zhrnutie práce na začiatku ponúka vysvetlenie, o čom sa v nasledujúcich riadkoch dočítame. Ivan Rumánek pútavo priblížil japonské mytologické pojmy bórei (duch mŕtveho) a marebitó (rituálny návštevník z onoho sveta), ktoré, ak budem citovat' autora, „sa vymykajú klasickému religionistickému pohl'adu na Japonsko". Text sa venuje v detailoch manuskriptovým dielam zo 17. storočia, ktoré sú prameňom k tradičnému japonskému divadlu kabuki. Rozbor samotnej mytologickej reflexie je okrajový, venuje sa viac literárnej časti, čo však nemení kvalitu príspevku. Autorovi však nemožno upriet' jeho dôkladný rozbor témy a originálnost'.

L’ubica Obuchová spracovala vo svojom príspevku nezvyčajnú tému s názvom Č́nsky vesmírny program a mytologické názvoslovie. Uvádza niekol'ko príkladov mytologických pomenovaní, ktoré využíva vesmírny program Č́ńnskej l'udovej republiky aj v medzinárodných súvislostiach. Nie je prekvapujúcim faktom, že krajina so silným autoritatívnym zriadením využíva k posilneniu národnej identity symboly, ktoré majú pôvod v l'udovej slovesnosti. Naopak, z hl'adiska ateistického prístupu štátnej ideológie to môže prekvapit' nejedného človeka. Je zrejmé, že týmto spôsobom dostáva aj bežný čínsky občan pocit podiel'ania sa na úspechoch svojej krajiny, ktoré dosahuje vo vývoji nových technológií. Podotkol by som fakt, že pokým v štúdii Zhang Czirákovej sa spomína drak ako jeden z najdôležitejších symbolov, vo vesmírnom programe sa vyskytuje len sporadicky. K tomuto faktu pristupuje Obuchová aj v závere, pričom nedáva konečnú odpoved'.

Zvieratá $v$ japonských mýtoch a legendách od religionistky a japanologičky Zuzany Kubovčákovej je názov druhej témy, ktorá sa viaže k japonskej kultúre. V štúdii sa bližšie zameriava na hady, ktoré majú v japonskej mytológii kladný aj záporný charakter. Taktiež analyzuje pojem mýtodejiny - prelínanie mytologického naratívu s historicky doloženými postavami. Rozdel'uje vek božstiev a vek l'udí a snaží sa oddelit' mýtickú látku od historicky doložených udalostí. Rozsah štúdie pravdepodobne nedovolil rozoberat' tému do úplných detailov, ale v tomto prípade by bolo vhodné doplnit' aj pohl'ad významného japonského religionistu Atsuhiko Yoshida. Práve Yoshida prišiel s objavom, ktorý nachádza paralely medzi európskou a japonskom verziou súboja hromovládcu s hadom. Kubovčáková tento súboj opisuje v časti, ked' Susanoo, nebeské božstvo hromu, búrok a morí, zabíja hada Jamata no Oroči. Prácu Japanes 
Mythology and Indoeuropean Trifunctional System ${ }^{3}$ považujem za vhodné doplnenie tejto témy, nakol'ko sa nenachádza ani v konečnom bibliografickom zozname. Pozornost' v závere venuje autorka ambivalentnému charakteru hadov, ktoré môžu vystupovat' ako nebezpečenstvo pre l'udský svet, ale po uzmierení aj ako ochranné božstvo.

Samotné objavenie Tróje, ktorá bola považovaná len za neexistujúce mesto z legiend, prinieslo zlom v pohl'ade na mýtické udalosti Homérových eposov. V roku 2003 boli na ostrove Flores nájdené kostrové pozostatky l'udí vel'mi nízkeho vzrastu, a to prinieslo nové zamyslenie nad témou mýtických stavitel'ov v Polynézii. Analýzu mýtov o trpasličích l'ud'och a ich stavitel'stve $v$ tejto oblasti rozpracovala Martina Bucková z Ústavu orientalistiky Slovenskej akadémie vied, kde sa venuje polynézskym štúdiám. V texte s názvom Mýtickí stavitelia v Polynézii. Analýza mýtov o „trpasličích l'ud'och" sa zamerala na mýtus o trpasličích l'ud'och Menehune z Havajských ostrovov a postupne popisuje ich charakteristiku, pôvod a stavitel'skú činnost'. Ďalej sa dostáva aj k iným etnikám, pri ktorých sumarizuje poznatky popredných bádatel'ov v tejto oblasti. Štúdia končí touto kapitolou a neponúka samostatný oddelený záver. Jej slabinou sú početné preklepy v slovách a mnohé chyby. Posledná veta textu vyznieva rozpačito: „Zdá sa, že mýty o trpasličích l'ud'och nie sú len fikciou, ale opisujú skutočných dávnych obyvatel’ov Oceánie“ (s. 175). Hodnotiaci prvok reálnosti mýtického naratívu s negatívnym zafarbením však považujem za nešt’astný prístup z pohl'adu religionistiky.

Egyptské hrošie božstvá a ich vzt'ah k božstvám a mytologickým postavám starovekého orientu a východného Stredomoria je názov štúdie Veroniky Dubcovej, archeologičky a egyptologičky, rovnako z Ústavu orientalistiky SAV. Ako uvádza autorka, štúdia predstavuje zhrnutie dizertačnej práce obhájenej v roku 2018 na Inštitúte pre klasickú archeológiu Viedenskej univerzity. Prvá čast' sa venuje hroším božstvám v Egypte, pôvodu ich zobrazení na pečatných amuletoch a skarabeoch, ale aj rôznych predmetoch dennej potreby. Popisy sprevádzajú vyobrazenia z odbornej literatúry, ktorá je náležite citovaná. Autorka d'alej pokračuje porovnávaním analógie týchto božstiev so sýrsko-palestínskou oblast'ou, kde sa prejavuje zobrazovanie rovnako na pečatidlách. A taktiež aj v egejskej oblasti doby bronzovej, kde prezentuje tézu o inšpirácii z oblasti Egypta. Odborníkmi tu dostáva hrošie božstvo pomenovanie minojský génius. Za prínosnú považujem predovšetkým čast' o medzikultúrnej výmene náboženských motívov, ktorú sama autorka považuje za jeden najkomplikovanejších javov, ktoré sprevádzajú medzikultúrne kontakty. Štúdia

\footnotetext{
3 YOSHIDA, Atsuhiko: Japanese Mythology and the Indo-European Trifunctional System. In: Diogenes. Vol. 25, Issue 98, 1977, s. 93 - 116.
} 
Veroniky Dubcovej je z hl'adiska využitia zdrojov a kvantity prezentovanej bibliografie na vel'mi vysokej úrovni, povedal by som, že v niektorých ohl'adoch vyčnieva z radu jej kolegov.

Doktorandka historického ústavu SAV Alžbeta Szolomaiová sa venuje moderným dejinám Blízkeho východu a Severnej Afriky a islamskému radikalizmu. Do zborníka prispela štúdiou Džinovia v arabskej a islamskej mytológii a teológii. Úvod príspevku zachytáva vysvetlenie slova džin z perspektív rôznych historických zdrojov, ale aj súčasných autorov. Priestor v texte dostáva viacero citovaných publikácií a štúdií, čo odráža prehl'ad autorky textu v problematike islamského náboženského sveta. Rovnako ako v európskom priestore, aj v tom moslimskom sa niektoré archaické náboženské bytosti pretransformovali do náboženstva (krest’anstvo/islam) a l'udovej tradície. Môžeme ich nachádzat'v rozprávkach, čo ilustrovala autorka na príklade Rozprávok z tisíc a jednej noci. Džinov však nepopisuje vo svete veriaceho len ako niečo abstraktné a neexistujúce, ale ako skutočnú a integrálnu súčast' života moslima. V závere dodáva, že racionalizovaný svet Západu vníma tento fenomén odlišne ako veriaci človek a pomaly sa tento vplyv dostával aj do prostredia moslimských vzdelancov. Szolomaiová v tejto myšlienke zachytila jeden z hlavných problémov konfliktu ezoterického a exoterického nazerania na náboženský svet, ktorý sa zdá byt' bremenom aj pre mnohých religionistov či d'alších odborníkov.

Kult kiahní a iných nákazlivých chorôb u kaukazských národov je text Beáty Čiernikovej, religionistky a kaukazologičky, autorky publikácie $V$ tieni hory Ararat. ${ }^{4}$ Sakrálny charakter choroby, ktorý článok popisuje, je špecifický na Kaukaze a ako napovedá názov, má v tejto oblasti kultový rozmer. Kratšia štúdia popisuje mýtické aspekty spojené s liečbou choroby, ktorá je vo svojej podstate pozitívnou udalost'ou, nakol'ko miestni verili, že telo postihnutého navštívilo božstvo. Príspevku však chýba zretel'nejšie vnútorné členenie, nemá úvod a neposkytuje ani zhrnutie v závere, ktorý by priblížil výsledky či prínos štúdie.

Posledná štúdia v zborníku nesie názov Samskáry - hinduistické prechodové rituály. Výklad základných pojmov a popis jednotlivých rituálov $v$ životnom cykle hinduistu. Helena Hadvigová, doktorandka a indologička z Karlovej univerzity, v úvode vysvetl'uje pojem samskár. Ako som spomenul vyššie, je to dost' odlišný pojem od známejšie slova samsára a preklep v úvode tak vyznieva dost' nešt'astne. Štúdiu považujem za vel'mi dobre spracovaný úvod do problematiky hinduistických rituálov každodenného života. Nechýba práca s prameňmi a popis autentických

4 ČIERNIKOVÁ, Beáta: V tieni hory Ararat. Náboženstvá predkrest'anskej Arménie. Bratislava : Chronos, 2005. $193 \mathrm{~s}$. 
zdrojov (Manuov zákonník). Zaujímavost'ou je, že jednou zo zložiek samskár je tiež mantra - slovo, ktoré bolo sprofanované aj v slangovom prejave nášho jazyka. Článok nepoužíva tak intenzívne citovanie ako napríklad štúdia o hroších božstvách a pri niektorých menej pravdepodobných tvrdeniach som si citáciu musel dohl'adat’ sám. Ide predovšetkým o obrad prepichovania uší nazvaný Karnavédha, o ktorom text tvrdí (s. 263), že jeho pôvodný účel bol dekoratívny a neskôr sa pridal aj náboženský charakter. Tento postup je z religionistického hl'adiska a vývoja náboženských rituálov dost' nepravdepodobný, ${ }^{5}$ avšak literatúra, ktorú som dohl'adal na základe zoznamu použitej literatúry, sa zhoduje $\mathrm{s}$ tvrdením v texte. ${ }^{6}$

V závere môžem konštatovat', že rôznorodost' tém, ktorá je definovaná samotným názvom zborníka pôsobí neusporiadane. Styčný bod prác je abstraktný a jeho prienik je definovaný geografickým priestorom. Samotné štúdie majú odlišnú kvalitatívnu podobu a okrem preklepov v texte chýba niektorým aj jasne vymedzený úvod alebo záver. Minimalistické, no pútavé grafické spracovanie dáva publikácii celkom atraktívny rozmer a prípadný záujemca by po ňom mohol siahnut' aj vd’aka exotickým a neobvyklým témam.

Stanislav Gubančok

\footnotetext{
${ }^{5}$ Ku konkrétnejšiemu rozboru odporúčam pozriet’ publikáciu: ELIADE, Mircea: Pojednání o dějinách náboženství. Praha : Argo, 2004. 456 s.

6 PANDEY, Rajbali: Hindu samskaras. Socio-Religious study of the hindu sacraments. Delhi : Motilal Banarsidass, 2006, s. 102.
} 